\title{
PENELITIAN FORTIFIKASI IKAN PADA PENGOLAHAN PATOLO
}

\author{
Subaryono*), N. Indriati"), dan H. E. (rianto")
}

\begin{abstract}
ABSTRAK
Penelitian pengolahan patolo (keripik singkong fermentasi khas Gunung Kidul) dengan penambahan ikan telah dilakukan. Jenis ikan yang ditambahkan yaitu udang putih (Penaeus merguiensis), kerang darah (Anadara granosa) dan ikan beloso (Saurida tumbii). Bentuk penambahan yang dilakukan yaitu dalam bentuk mentah dan dikukus. Jumlah penambahan adalah 10,20 dan 30 persen bobot singkong. Selanjutnya terhadap produk yang dihasilkan dilakukan analisis organoleptik, kadar air, dan kadar protein. Terhadap produk yang mendapatkan penerimaan terbaik dilakukan pengamatan analisis komposisi proksimat dan aktivitas air. Hasil penelitian menunjukkan bahwa ikan yang paling baik untuk ditambahkan yaitu udang dengan bentuk dikukus sebanyak 20 persen. Penambahan ini dapat meningkatkan kadar protein produk dari $1,68 \%$ menjadi $7.01 \%$.
\end{abstract}

\begin{abstract}
Research on Fish Fortification for Patolo Production. By: Subaryono, N. Indriati, H. E. Irianto

Research on fortification of patolo (a typical Gunung Kidul fermented cassava crackers) with fisheries product had been done. Kinds of fish flesh added were white shrimp (Penaeus merguiensis), lizard fish (Saurida tumbil) and cockle shell (Anadara granosa). Steamed and uncooked fish flash at 10,20 and 30 percent of cassava weight were used in fortification. Parameters observed were organoleptic, moisture and protein content. Proximate analysis and water activity were done to the product of best acceptance. Research result showed that the suitable fish for fortification was steamed shrimp at concentration of 20 percent. The fortification improved protein content of product from $1,68 \%$ to $7.01 \%$.
\end{abstract}

KEYWORDS: fish fortification, patolo

\section{PENDAHULUAN}

Fortifikasi terhadap berbagai produk olahan yang sudah ada dan banyak dikonsumsi di masyarakat merupakan salah satu cara untuk meningkatkan status gizi masyarakat karena dengan fortifikasi ini diharapkan konsumen secara tidak langsung mengkonsumsi ikan dan bagi konsumen yang tidak atau kurang suka mengkonsumsi ikan secara langsung dapat mendapatkan sumber protein ikani dari produk-produk tersebut. Usaha fortifikasi telah berhasil dilakukan pada beberapa produk antara lain roti (Fawzya et al., 1994), kue (Sugiyono et al., 1994), mie (Peranginangin et al., $1994^{\mathrm{a}, \mathrm{b}}$ ) ; Anggawati et. al., 1994; Basmal et al., 1995), dan dalam kerupuk (Fawzya et al., 1986). Dalam penelitian ini fortifikasi dilakukan pada produk pangan tradisional patolo, yaitu salah satu makanan khas tradisional Gunung Kidul berupa sejenis kerupuk yang diolah dari singkong yang di fermentasi. Produk ini biasa dikonsumsi sebagai pelengkap makan dan camilan yang sangat disukai masyarakat Gunung Kidul. Pemasarannya bahkan telah meluas ke Yogyakarta, Semarang dan Jakarta. Data konsumsi per kapita penduduk terhadap produk tersebut belum tersedia, tetapi data produksi produk tersebut cukup besar yaitu sekitar $720 \mathrm{~kg} / \mathrm{bulan}$ (sumber: wawancara dengan produsen). Kandungan protein dalam produk ini rendah karena bahan utamanya adalah singkong yang merupakan sumber karbohidrat. Mengingat tingkat konsumsi ikan masyarakat Gunung Kidul yang masih rendah (kurang dari $30 \mathrm{~kg} / \mathrm{kapita} / \mathrm{tahun}$ ) dan kesukaan terhadap produk patolo sebagai pelengkap makan atau camilan cukup tinggi, maka usaha fortifikasi patolo dengan sumber

\footnotetext{
- Peneliti pada Pusat Riset Pengolahan Produk dan Sosial Ekonomi Kelautan dan Perikanan
} 
protein diharapkan dapat meningkatkan konsumsi protein mereka dan selanjutnya diharapkan dapat memperbaiki status gizi mereka yang masih rendah. Selain itu cara pengembangan produk ini relatif mudah, dan kemungkinan diterima konsumen cukup besar mengingat konsumen telah terbiasa mengkonsumsi produk tersebut. Di samping itu bahan baku untuk pengolahan produk tersebut cukup banyak tersedia di masyarakat yaitu singkong (ketela pohon) yang harganya relatif murah (Ditjen Industri Kecil. 1985).

Tujuan yang diharapkan dari kegiatan ini adalah untuk mengetahui pengaruh jenis ikan, bentuk penambahan dan konsentrasi penambahan terhadap kualitas produk patolo yang dihasilkan. Tujuan utama penelitian ini adalah untuk mendapatkan teknik pengolahan patolo ikan yang dapat meningkatkan kadar protein pada produk dan secara organoleptik dapat diterima konsumen. Bila produk ini diproduksi di masyarakat diharapkan dapat meningkatkan konsumsi ikan sebagai sumber protein penduduk Indonesia khususnya Gunung Kidul yang masih rendah, terutama bagi yang tidak suka mengkonsumsi ikan secara langsung.

\section{BAHAN DAN METODE}

Bahan baku yang digunakan berupa ketela pohon (singkong) yang diperoleh dari pengrajin patolo di kecamatan Tepus Gunung Kidul, udang putih dari Eretan Indramayu dan kerang darah dari Muara Angke Jakarta. Ketela pohon dikupas kemudian dicuci dan diparut. Ikan, udang dan kerang setelah dipisahkan dari cangkangnya/tulangnya kemudian dicuci dan digiling menjadi daging lumat. Selanjutnya daging lumat ini dibekukan dan dijaga tetap beku selama transportasi ke tempat penelitian di Gunung Kidul. Hasil analisis proksimat singkong dan berbagai jenis ikan dapat dilihat dalam Tabel 1.
Faktor yang diteliti dalam penelitian ini meliputi :

1. Jenis ikan: jenis ikan yang digunakan yaitu kerang darah, udang dan ikan beloso. Bagian ikan yang digunakan hanya dagingnya saja.

2. Bentuk penambahan: ikan ditambahkan dalam bentuk mentah dan dikukus. Ikan ditambahkan dalam bentuk daging lumat yang telah dicuci dengan air dingin

3. Jumlah Penambahan : jumlah ikan yang ditambahkan sebanyak 10,20 dan 30 persen dihitung dari bobot bahan baku utama yaitu ampas singkong yang sudah difermentasi.

Selain itu dilakukan pula pembuatan produk kontrol (tanpa penambahan ikan) untuk melihat perbedaan produk yang dihasilkan. Proses pengolahan patolo dalam penelitian ini dapat dilihat dalam Gambar 1.

Pencetakan patolo menggunakan lepekan (piring cetakan terbuat dari plastik) dengan diameter bagian dalam 7-8 $\mathrm{cm}$. Produk kering yang dihasilkan memiliki diameter $6-7,5 \mathrm{~cm}$ dan ketebalan $3 \mathrm{~mm}$. Pengukusan dilakukan dalam alat pengukus (dandang) dengan disusun secara bertumpuk. Setelah matang (sekitar 10 menit) patolo diangkat, didinginkan dan dilepaskan dari piring cetakan lalu dijemur. Pengeringan menggunakan panas matahari selama 7 jam (suhu $39^{\circ} \mathrm{C}$ ) dengan asumsi sampai bobot produk konstan (Gambar 11). Bumbu yang digunakan yaitu garam $2 \%$, bawang putih $2 \%$ dan penyedap masakan $1 \%$ dari bobot bahan baku. Pengamatan yang dilakukan meliputi sifat organoleptik produk, analisis kadar air, kadar protein, dan daya kembang produk ketika digoreng. Untuk produk terpilih dilakukan analisis proksimat dan aktivitas air (AOAC. 1980, Sudarmadji, et al., 1984; Sudarmadji, et al., 1989). Produk terpilih

Tabel 1. Komposisi proksimat bahan utama yang digunakan dalam pembuatan patolo

Table 1. Proximate composition of raw material for patolo processing

\begin{tabular}{lccccc}
\hline \multicolumn{1}{c}{ Bahan } & $\begin{array}{c}\text { Air } \\
\text { Moisture } \\
(\%)\end{array}$ & $\begin{array}{c}\text { Protein } \\
\text { Protein } \\
(\%)\end{array}$ & $\begin{array}{c}\text { Lemak } \\
\text { Fat } \\
(\%)\end{array}$ & $\begin{array}{c}\text { Abu } \\
\text { Ash } \\
(\%)\end{array}$ & $\begin{array}{c}\text { Karbohidrat } \\
\text { Carbohydrate } \\
(\%)\end{array}$ \\
\hline Ketela pohon/cassava & 56.24 & 1.48 & 0.18 & 0.75 & 41.35 \\
Udang putih/White shrimp & 84.66 & 14.39 & 0.47 & 0.34 & 0.14 \\
Kerang darah/Cockle shell & 82.47 & 14.01 & 1.19 & 0.19 & 1.34 \\
Ikan beloso/Lizard fish & 79.24 & 17.32 & 1.87 & 0.90 & 0.67 \\
\hline
\end{tabular}




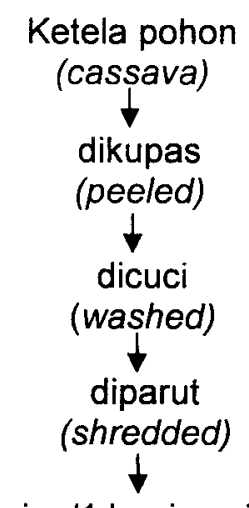

Ditambah air sebanyak 1,5 bagian/1 bagian singkong ( $\mathrm{v} / \mathrm{b})$, diaduk dan dipress (water added 1.5 portion/1 portion of cassava $(v / w)$, stirred and pressed)

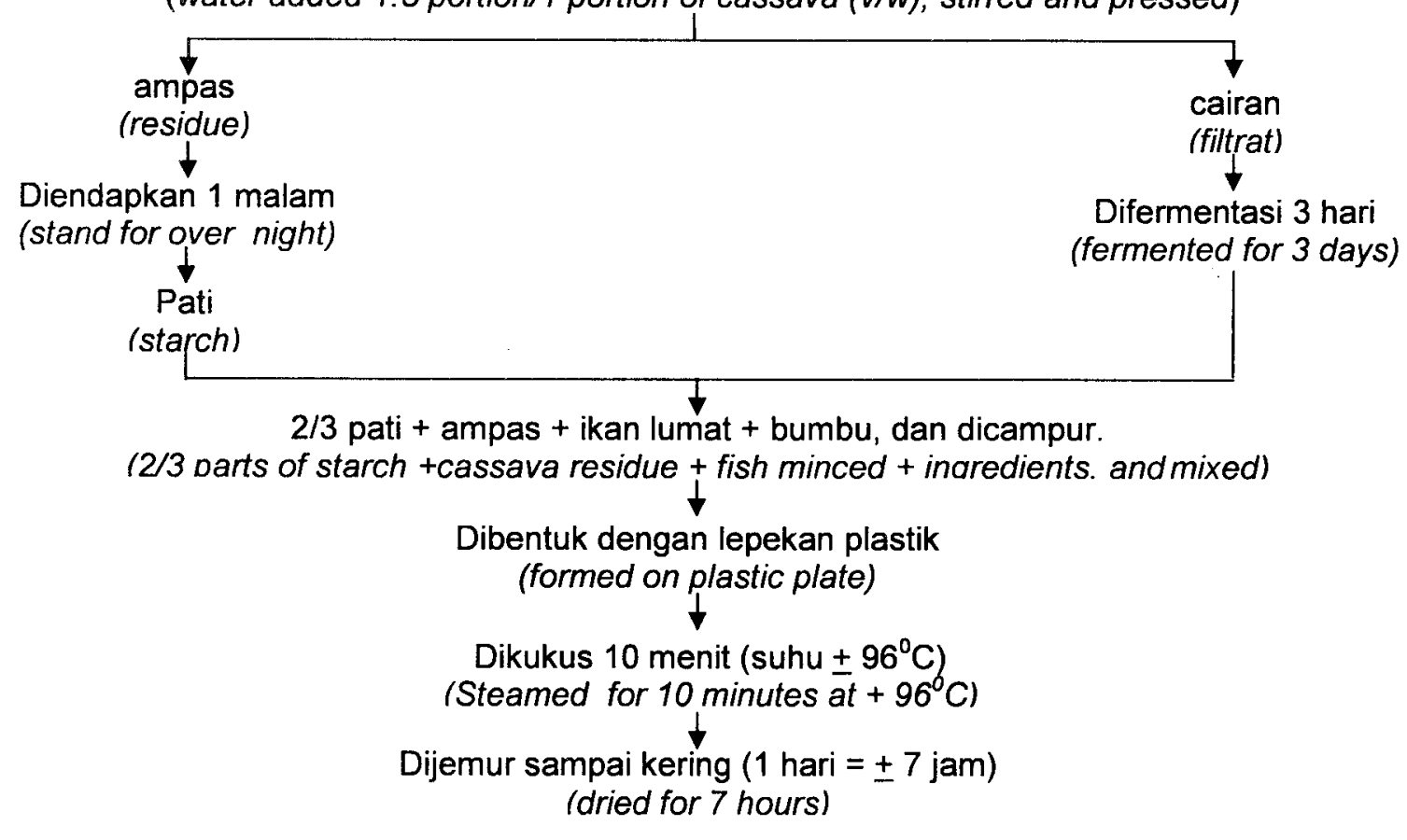

Gambar 1. Proses pengolahan patolo

Figure1. Process of patolo production

adalah produk yang memiliki nilai organoleptik penerimaan tertinggi untuk tiap jenis ikan baik dengan perlakuan dikukus maupun mentah.

Pengukuran daya kembang produk dilakukan dengan mengukur luas permukaan produk patolo sebelum (LO) dan sesudah digoreng $(L 1)$. Daya kembang dinyatakan dalam $(L 1-L O) / L O \quad \times 100 \%$. Dari data yang diperoleh selanjutnya dilakukan analisis varian (anova) dan dilanjutkan dengan uji LSD pada selang kepercayaan $95 \%$ (Gomez dan Gomez, 1995).

\section{HASIL DAN PEMBAHASAN}

\section{Penampakan}

Hasil analisis statistik terhadap penam- pakan patolo menunjukkan bahwa pada $\mathrm{P} \geq 95$, perlakuan penambahan kerang (4.63) berbeda nyata dengan ikan beloso (6.65) dan udang (6.85), dimana antara penambahan ikan beloso dan udang tidak berbeda nyata. $\mathrm{Hal}$ ini tertutama disebabkan karena pada penambahan kerang penampakan produk patolo menjadi menurun karena permukaan produk yang tidak merata karena sifat daging kerang yang liat sehingga lebih sukar untuk digiling dibandingkan ikan beloso dan udang.

Perlakuan pengukusan terhadap semua jenis ikan (5.89) tidak memberikan pengaruh berbeda nyata dengan tanpa pengukusan (6.20).

Sedangkan konsentrasi penambahan ikan menunjukkan bahwa penambahan pada 
konsentrasi $30 \%$ (5.72) tidak berbeda nyata dengan $20 \%(6.02)$ tetapi berbeda nyata dengan $10 \%$ (6.41), sedangkan antara konsentrasi $10 \%$ dengan $20 \%$ tidak berbeda nyata. Apabila dibandingkan dengan produk kontrol (7.61), maka perlakuan yang tidak berbeda nyata adalah produk dengan penambahan udang kukus $10 \%$ (7.17), udang kukus $20 \%(7.19)$ ikan beloso mentah $10 \%$ (6.99) dan ikan beloso kukus 10\% (7.06). Selain keempat produk tersebut nilai penampakan lebih rendah dibandingkan dengan kontrol. Nilai organoleptik penampakan dapat dilihat pada Gambar 2.

\section{Warna}

Hasil analisis statistik terhadap warna patolo menunjukkan bahwa pada $P \geq 95$, penambahan kerang (4.42) sangat berbeda nyata dengan penambahan ikan beloso (6.50) dan udang (6.78), sedangkan antara penambahan ikan beloso dan udang tidak berbeda nyata. Hal ini disebabkan karena adanya warna hitam pada daging kerang yang menyebabkan produk patolo berwarna hitam sehingga menurunkan nilai organoleptik warnanya. Penambahan dalam bentuk mentah (6.09) ternyata memberikan warna lebih baik dibandingkan dalam bentuk dikukus (5.71). Hal ini disebabkan karena pengukusan menyebabkan warna bahan baku ikan menjadi lebih dominan, bahkan pada bahan baku kerang warna menjadi lebih hitam. Uji konsentrasi penambahan ikan menunjukkan bahwa penambahan $30 \%$ (5.52) tidak berbeda nyata dengan $20 \%(5.91)$ tetapi berbeda nyata dengan $10 \%(6.26)$, sedangkan antara $10 \%$ dengan $20 \%$ tidak berbeda nyata. Apabila dibandingkan dengan kontrol (7.54), maka produk yang tidak berbeda nyata adalah produk dengan penambahan udang kukus $10 \%$ (7.07) dan udang kukus 20\% (7.30). Selain kedua produk tersebut warna yang dihasilkan lebih rendah dibandingkan dengan kontrol. Nilai organoleptik warna patolo dapat dilihat pada Gambar 3.

\section{Bau}

Hasil analisis statistik bau patolo menunjukkan bahwa pada $\mathrm{P} \geq 95$ penambahan

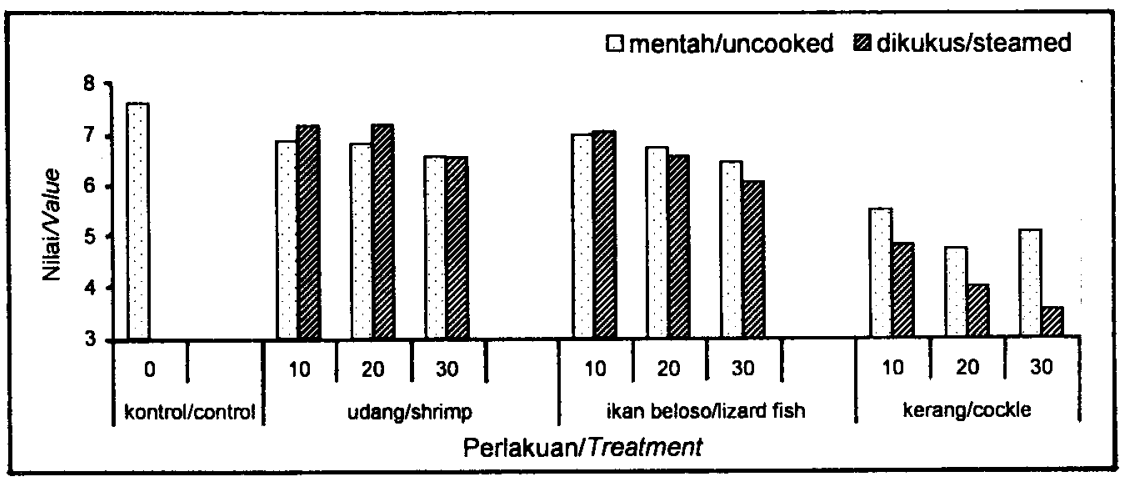

Gambar 2. Nilai organoleptik penampakan patolo

Figure 2. Organoleptic scores of patolo appearance

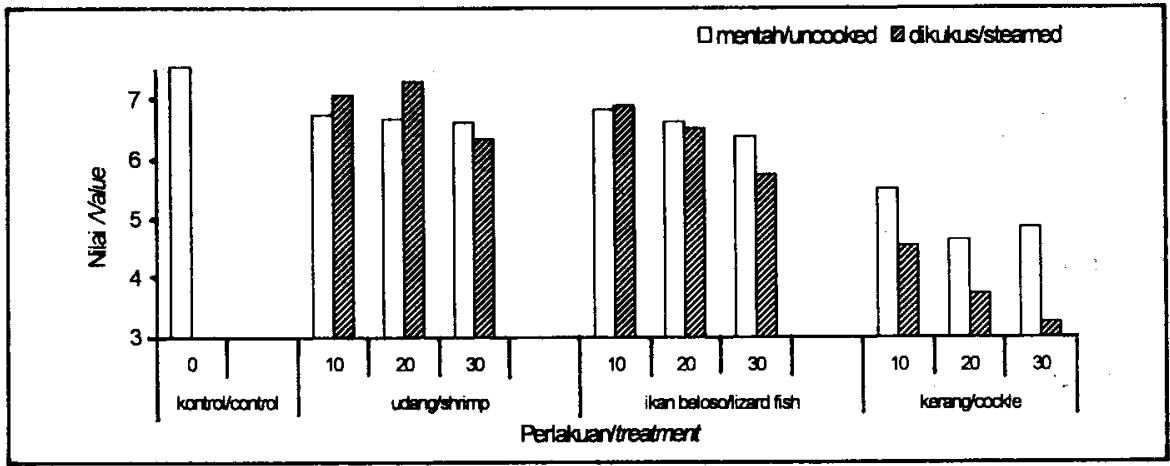

Gambar 3. Nilai organoleptik warna patolo

Figure 3. Organoleptic scores of patolo colour 
udang (6.59) tidak berbeda nyata dengan penambahan ikan beloso (6.36) dan berbeda nyata dengan penambahan kerang (5.46). Penambahan dalam bentuk dikukus (6.05) tidak berbeda nyata dengan penambahan mentah (6.22), sedangkan uji konsentrasi penambahan ikan menunjukkan bahwa ketiga konsentrasi tersebut tidak berbeda nyata.

Bila dibandingkan dengan produk kontrol (6.89), maka semua produk dengan penambahan udang dan ikan beloso untuk semua perlakuan dan konsentrasi tidak berbeda nyata, tetapi untuk penambahan kerang semua perlakuan dan konsentrasi berbeda nyata. Hal ini menunjukkan bahwa adanya bau amis pada kerang begitu kuat sehingga berpengaruh pada produk akhir patolo yang dihasilkan. Nilai organoleptik bau patolo ikan dapat dilihat dalam Gambar 4.

\section{Rasa}

Hasil analisis statistik terhadap nilai organoleptik rasa menunjukkan bahwa pada $P \geq 95$ penambahan kerang (5.82) berbeda nyata dengan penambahan ikan beloso (6.79) dan udang (7.25), sedangkan antara penambahan udang dengan ikan beloso. juga berbeda nyata. Dari hasil ini terlihat bahwa adanya rasa ikan dalam produk cukup dominan dan panelis dapat membedakan rasa ketiga jenis produk tersebut.

Penambahan udang ke dalam produk patolo memberikan nilai organoleptik rasa yang paling tinggi dibandingkan dengan penambahan ikan beloso maupun kerang. Hal ini disebabkan karena dalam daging udang terdapat komponen-komponen penghasil flavor dan rasa yang umumnya disukai oleh panelis yang lebih dominan dibanding dalam daging ikan beloso maupun kerang. Pada penambahan kerang justru nilai rasa menjadi turun karena adanya bau amis dan warna serta penampakan yang tidak menarik yang turut mempengaruhi penilaian rasa produk oleh panelis.

Bentuk penambahan antara dikukus (6.50) dengan mentah (6.75) tidak berbeda nyata. Dari ketiga konsentrasi penambahan, tidak terlihat adanya perbedaan yang nyata antara penambahan 10,20 dan 30 persen. Jika dibandingkan dengan kontrol (6.49), maka produk yang tidak berbeda nyata pada $P \geq 95$ yaitu produk dengan penambahan udang

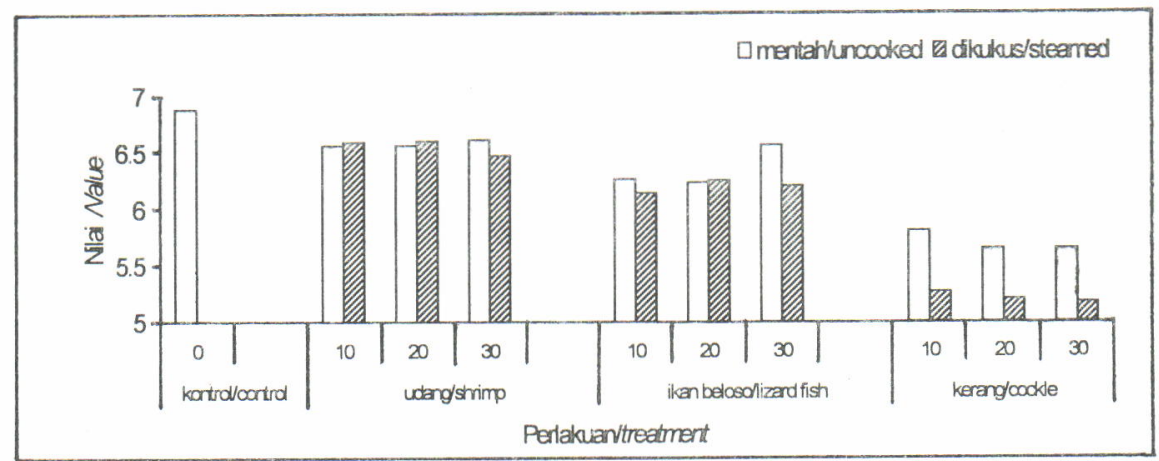

Gambar 4. Nilai organoleptik bau patolo

Figure 4. Organoleptic scores of patolo odour

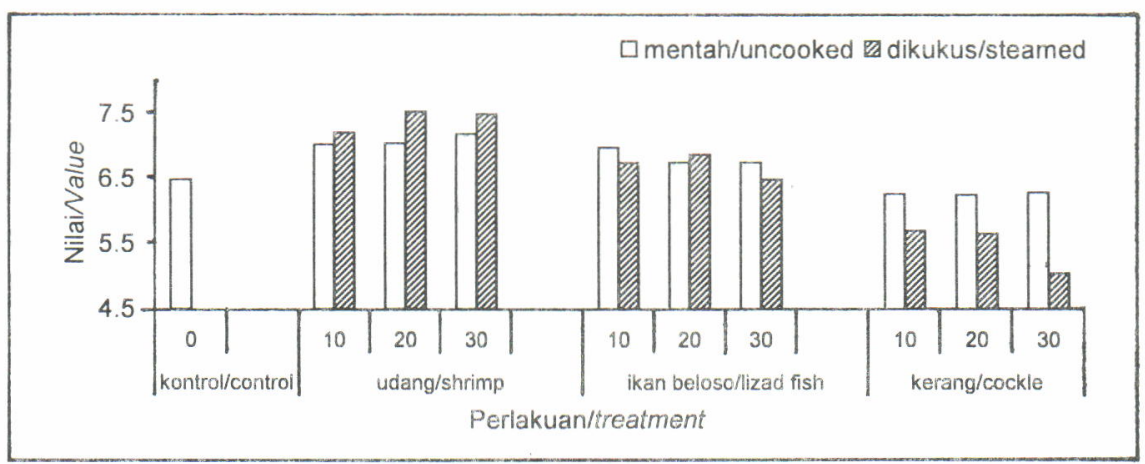

Gambar 5. Nilai organoleptik rasa patolo Figure 5. Organoleptic scores of patolo taste 
mentah $10 \%$ (7.03), ikan beloso mentah $10 \%$ (6.99), ikan beloso mentah $20 \%$ (6.76), ikan beloso mentah $30 \%(6.76)$, ikan beloso kukus $10 \%$ (6.75), ikan beloso kukus 20\% (6.88), ikan beloso kukus $30 \%(6.5)$, kerang mentah $10 \%$ (6.27), kerang mentah 20\% (6.26) dan kerang mentah $30 \%$ (6.3). Produk dengan penambahan udang mentah $20 \%$ (7.05), udang mentah $30 \%$ (7.20), udang kukus $10 \%$ (7.22), udang kukus $20 \%$ (7.54) dan udang kukus $30 \%$ (7.50) berbeda nyata dan lebih tinggi dibandingkan produk. Sedangkan produk dengan penambahan kerang kukus untuk ketiga konsentrasi semuanya berbeda nyata dengan kontrol dan nilai organoleptik rasanya lebih rendah. Nilai organoleptik rasa dapat dilihat pada Gambar 5.

\section{Kerenyahan}

Hasil analisis statistik terhadap organoleptik kerenyahan patolo menunjukkan bahwa pada $\mathrm{P} \geq 95$ penambahan udang (6.85) berbeda nyata dengan penambahan ikan beloso (6.52) dan kerang (5.82), sedangkan antara penambahan ikan beloso dan kerang juga berbeda nyata. Perbedaan nilai organoleptik kerenyahan ini kemungkinan besar dipengaruhi oleh kondisi tekstur daging ketiga jenis ikan yang ditambahkan, dimana tekstur udang lebih halus dan lunak dibandingkan ikan beloso dan kerang. Daging kerang segar lebih liat dan akan menjadi keras ketika digoreng. Bentuk penambahan mentah (6.24) berbeda nyata dengan penambahan dikukus (6.56).

Hal ini kemungkinan disebabkan karena pada penambahan ikan dalam bentuk mentah, adanya air dan lendir dari daging udang, ikan dan kerang menyebabkan efektifitas proses pencampuran menjadi lebih. rendah, sehingga distribusi daging lumat dalam adonan menjadi tidak homogen. Hal ini kemungkinan yang menjadi sebab kerenyahan produk patolo yang ditambahkan daging lumat dalam bentuk mentah menjadi lebih rendah. Dari ketiga konsentrasi ikan yang ditambahkan, terlihat bahwa penambahan pada konsentrasi $30 \%$ (6.23) tidak berbeda nyata dengan $20 \%$ (6.41) tetapi berbeda nyata dengan $10 \%$ (6.56), dimana antara penambahan $20 \%$ dengan $10 \%$ tidak berbeda nyata.

Hal ini menunjukkan bahwa penambahan ikan pada konsentrasi tertentu akan menurunkan nilai kerenyahan produk. Apabila dibandingkan dengan kontrol (7.09), maka produk patolo yang tidak berbeda adalah produk dengan penambahan udang kukus $10 \%$ (7.34), udang kukus 20\% (7.32) dan udang kukus $30 \%$ (7.25). Selain ketiga produk tersebut nilai kerenyahan produk lebih rendah dibanding kontrol. Nilai organoleptik kerenyahan dapat dilihat pada Gambar 6.

\section{Penerimaan}

Hasil analisis statistik terhadap nilai organoleptik penerimaan menunjukkan bahwa pada $\mathrm{P} \geq 95$ penambahan udang (6.97) berbeda nyata dengan penambahan ikan beloso (6.66) dan kerang (5.31), dimana antara penambahan ikan beloso dan kerang juga berbeda nyata.

Perbedaan nilai organoleptik penerimaan ini dipengaruhi oleh penampakan, warna dan rasa produk. Dari ketiga jenis ikan yang ditambahkan terlihat bahwa udang memiliki pengaruh paling baik terhadap ketiga parameter organoleptik tersebut dibandingkan dua jenis ikan lainnya. Bentuk penambahan

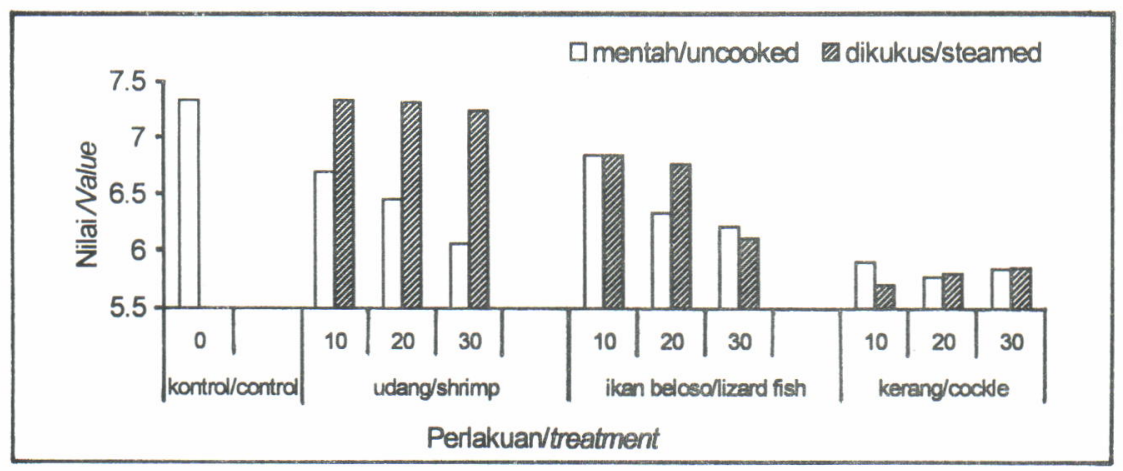

Gambar 6. Nilai organoleptik kerenyahan patolo

Figure 6. Organoleptic scores of patolo crispiness 
mentah (6.39) tidak berbeda nyata dengan penambahan dikukus (6.23). Dari ketiga konsentrasi ikan yang ditambahkan, terlihat bahwa penambahan pada konsentrasi $30 \%$ (6.10) tidak berbeda nyata dengan $20 \%$ (6.31) tetapi berbeda nyata dengan 10\% (6.53), sedangkan antara penambahan $20 \%$ dengan $10 \%$ tidak berbeda nyata. Hal ini menunjukkan bahwa penambahan ikan pada konsentrasi tertentu akan menurunkan nilai penerimaan produk, dan konsentrasi penambahan sebaiknya berada antara 10-20 persen. Apabila dibandingkan dengan kontrol (7.09), maka nilai penerimaan produk patolo ikan untuk penambahan udang mentah dan udang kukus untuk semua konsentrasi serta ikan beloso mentah $10 \%$, ikan beloso kukus $10 \%$ dan $20 \%$ tidak berbeda nyata, tetapi untuk produk dengan penambahan ikan beloso mentah $20 \%$ dan $30 \%$, ikan beloso kukus $30 \%$, serta kerang mentah dan kerang kukus untuk semua konsentrasi berbeda nyata dan lebih rendah nilainya. Nilai organoleptik penerimaan dapat dilihat pada Gambar 7.

\section{Kadar Air}

Hasil analisis statistik kadar air patolo menunjukkan bahwa pada $\mathrm{P} \geq 95$ penambahan ikan beloso (12.45\%), kerang (12.58\%) dan udang $(12.39 \%)$ tidak berpengaruh nyata terhadap perubahan kadar air produk.

Hal ini menunjukkan bahwa pengeringan dengan sinar matahari yang dilakukan selama sekitar 7 jam telah menurunkan kadar air sampai bobot patolo menjadi konstan (Gambar 11). Penurunan kadar air sampai bobot konstan inilah yang menyebabkan kadar air dalam produk patolo hampir sama sekitar $12 \%$.

Penambahan ikan dalam bentuk mentah dan dikukus tidak berpengaruh terhadap kadar air produk yang dihasilkannya. Dari ketiga konsentrasi ikan yang ditambahkan, terlihat bahwa penambahan pada konsentrasi $10 \%(12.24 \%)$ tidak berbeda nyata dengan $20 \%(12.24 \%)$ tetapi berbeda nyata dengan $30 \%(12.94 \%)$. Hal ini disebabkan karena pada penambahan sebesar $30 \%$ bagian

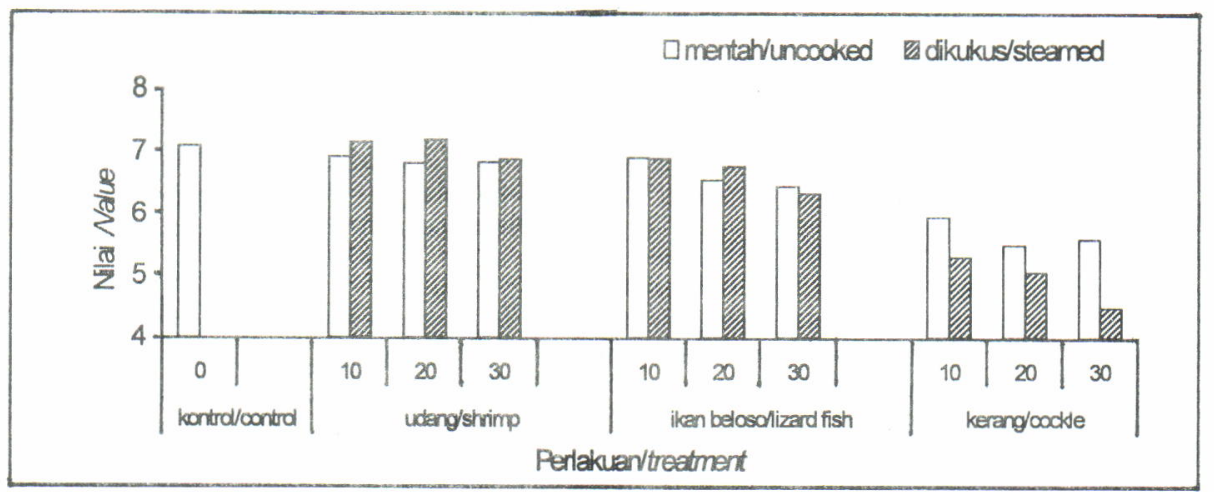

Gambar 7. Nilai organoleptik penerimaan patolo

Figure 7. Organoleptic scores of patolo acceptance

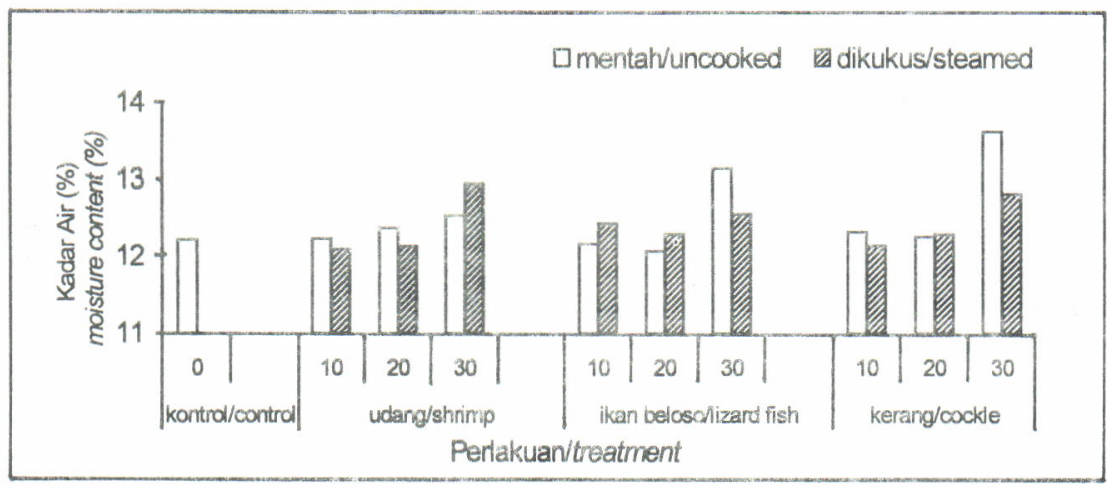

Gambar 8. Hasil analisis kadar air patolo

Figure 8. Moisture content of patolo 
daging ikan akan menahan air sehingga lebih sukar untuk dikeringkan dibanding pada konsentrasi $10 \%$ dan $20 \%$. Apabila dibandingkan dengan kadar air produk kontrol $(12.22 \%)$, maka hampir semua perlakuan dan semua konsentrasi tidak berbeda nyata kecuali untuk produk dengan penambahan udang kukus $30 \%(12.95 \%)$, ikan beloso mentah 30\% (13.15\%), kerang mentah 30\% $(13.63 \%)$ dan kerang kukus 30\% (12.82\%). Hasil analisis kadar air patolo dapat dilihat pada Gambar 8.

\section{Kadar Protein}

Hasil analisis statistik kadar protein patolo menunjukkan bahwa pada $\mathrm{P} \geq 95$ penambahan kerang (5.88), berbeda nyata dengan udang (7.58) dan ikan beloso (8.82), dimana antara penambahan udang dan ikan beloso juga berbeda nyata. Hal ini disebabkan karena kadar protein bahan baku memang berbeda dimana untuk ikan beloso $17.32 \%$, udang $14.39 \%$ dan untuk kerang $14.01 \%$. Penambahan ikan dalam bentuk mentah $(6.86 \%)$ berbeda nyata dengan penambahan dalam bentuk dikukus $(7.99 \%)$. Hal ini disebabkan karena pada ikan yang dikukus terjadi penurunan kadar air, sehingga penambahan ikan kukus ke dalam adonan patolo dengan bobot yang sama akan lebih tinggi nilai proteinnya dibanding ikan mentah.

Dari ketiga konsentrasi ikan yang. ditambahkan, terlihat bahwa pada $P \geq 95$, penambahan pada konsentrasi $10 \%(4.23 \%)$ berbeda nyata dengan $20 \%(7.26 \%)$ dan berbeda nyata pula dengan $30 \%(10.78 \%)$. Apabila dibandingkan dengan kadar protein produk kontrol (1.61\%), maka semua perlakuan dan semua konsentrasi berbeda nyata kecuali untuk produk dengan penambahan kerang mentah $10 \%(2.34 \%)$. Peningkatan kadar protein tertinggi terjadi pada penambahan udang kukus $30 \%$ menjadi sebesar $12.1 \%$. Hasil analisis kadar air patolo dapat dilihat pada Gambar 9 .

\section{Penganatan Daya Kembang Patolo Ketika digoreng}

Hasil analisis statistik daya kembang patolo menunjukkan bahwa pada $\mathrm{P} \geq 95$ penambahan kerang $(77.80 \%)$ tidak berbeda nyata dengan udang $(77.25 \%)$ dan berbeda nyata dengan ikan beloso (54.32), sedangkan antara penambahan udang dan kerang tidak berbeda nyata. Hal ini kemungkinan disebabkan karena daging ikan beloso yang mempunyai protein paling tinggi juga memiliki kemampuan mengikat air yang lebih kuat dan sulit untuk mengembang ketika digoreng. Penambahan ikan dalam bentuk mentah $(65.79 \%)$ tidak berbeda nyata dengan penambahan dalam bentuk dikukus $(73.49 \%)$. Dari ketiga konsentrasi ikan yang ditambahkan, terlihat bahwa penambahan pada konsentrasi $10 \%(73.26 \%)$ tidak berbeda nyata dengan $20 \%(67.03 \%)$ dan berbeda nyata dengan $30 \%(68.63 \%)$. Dari hal ini dapat diketahui bahwa penambahan ikan ke dalam produk patolo sebaiknya tidak lebih dari $20 \%$ karena akan menurunkan daya kembang patolo ketika digoreng. Apabila dibandingkan dengan daya kembang produk kontrol (82.91\%), maka hampir semua perlakuan dan semua konsentrasi tidak berbeda nyata kecuali untuk produk dengan penambahan ikan beloso mentah 10\% (54.69\%), ikan beloso mentah $20 \%$ (50.05), ikan beloso mentah 30\% (53.26) dan kerang mentah $20 \%(67.86 \%)$. Hasil analisis daya kembang patolo dapat dilihat pada Gambar 10.

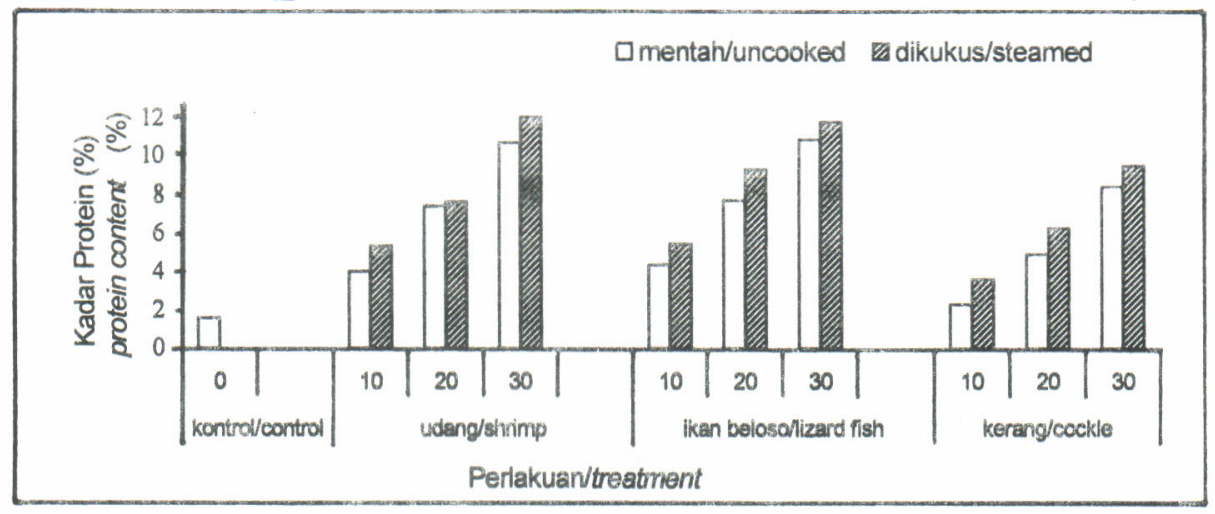

Gambar 9. Hasil analisis kadar protein patolo Figure 9. Protein content of patolo 


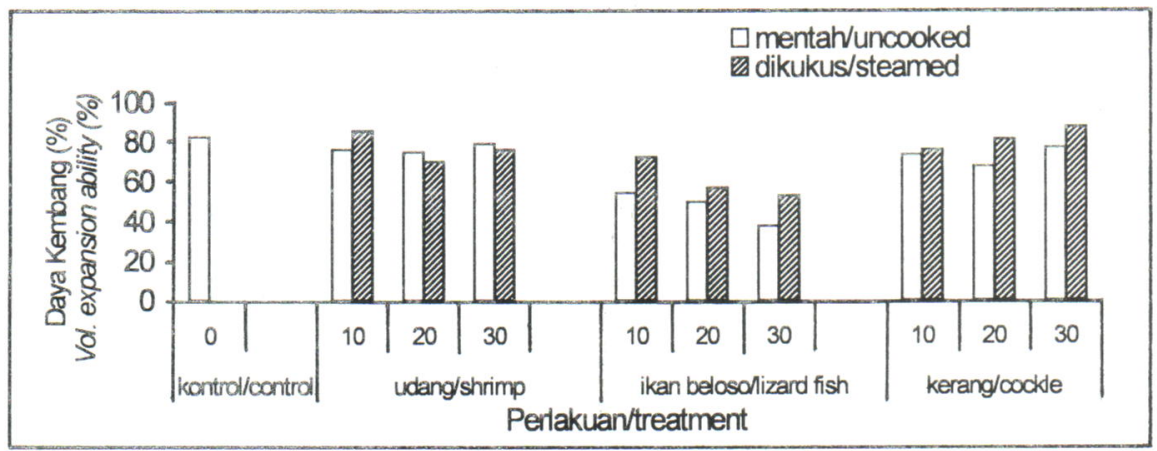

Gambar 10. Daya kembang patolo ketika digoreng

Figure 10. (volumetric) expansion ability of patolo during frying

Analisis Komposisi Proksimat Produk Terpilin

Produk patolo terpilih adalah produk yang memiliki nilai penerimaan terbaik untuk masing-masing jenis ikan baik dengan penambahan mentah maupun dikukus. Komposisi proksimat dapat dilihat dalam Tabel 2.

Dari tabel tersebut terlihat bahwa komposisi kadar air hampir sama untuk setiap perlakuan, yaitu sekitar $12 \%$. Kadar protein pada penambahan udang kukus $20 \%$ adalah paling tinggi yaitu sebesar $7.01 \%$ dan untuk kontrol paling rendah yaitu $1.68 \%$. Kadar lemak dan abu relatif hampir sama untuk setiap perlakuan. Pada analisis karbohidrat terlihat bahwa produk kontrol memiliki nilai paling tinggi $85.22 \%$, hal ini tentunya disebabkan karena pada produk dengan penambahan ikan terjadi pengurangan proporsi bahan ketela pohon dan digantikan dengan bagian ikan yang memiliki nilai karbohidrat jauh lebih rendah. Hal ini tentunya akan menurunkan kadar karbohidrat dalarn produk patolo.

\section{Analisis Aktivitas Air Produk Terpilih}

Hasil analisis aktivitas air produk patolo terpilih untuk masing-masing jenis ikan dapat dilihat dalam Tabel 3. Dari tabel tersebut terlihat bahwa nilai aktivitas air patolo hampir sama, yaitu berada pada kisaran $0,4-0,5$. Nilai aktivitas air tersebut menurut Winarno (1993) masih dalam kondisi yang aman untuk penyimpanan mengingat umumnya bakteri dan kapang dapat tumbuh dalam makanan pada nilai aktivitas air sekitar 0.7. Semakin rendah nilai aktivitas air suatu bahan makanan, maka daya awet produk akan semakin baik karena kemungkinan hidup mikroorganisme dan kapang semakin kecil, sehingga kerusakan yang ditimbulkannya juga semakin kecil. Aktivitas air suatu bahan makanan erat sekali kaitannya dengan kadar air bahan makanan. Umumnya semakin

Tabel 2. Hasil analisis proksimat produk patolo dengan penerimaan terbaik

Table 2. Proximate analysis of patolo with the best acceptance

\begin{tabular}{|c|c|c|c|c|c|c|}
\hline Ikan/Fish & $\begin{array}{c}\text { Perlakuan } \\
\text { Treatment (\%) }\end{array}$ & $\begin{array}{c}\text { Air } \\
\text { Moisture } \\
(\%)\end{array}$ & $\begin{array}{c}\text { Protein } \\
\text { Protein } \\
(\%)\end{array}$ & $\begin{array}{c}\text { Lemak } \\
\text { Fat } \\
(\%)\end{array}$ & $\begin{array}{c}\text { Abu } \\
\text { Ash } \\
(\%)\end{array}$ & $\begin{array}{c}\text { Karbohidrat } \\
\text { Carbohidrat } \\
(\%)\end{array}$ \\
\hline Kontrol/Control & - & 12.22 & 1.68 & 0.31 & 0.57 & 85.22 \\
\hline \multirow{2}{*}{ Udang/Shrimp } & $\begin{array}{c}\text { Mentah/ } \\
\text { Uncooked } 10\end{array}$ & 12.24 & 3.77 & 0.19 & 0.68 & 83.12 \\
\hline & Kukus/Steam 20 & 12.14 & 7.01 & 0.17 & 0.66 & 80.02 \\
\hline \multirow{2}{*}{$\begin{array}{l}\text { Ikan belosol } \\
\text { Lizard fish }\end{array}$} & $\begin{array}{c}\text { Mentah/ } \\
\text { Uncooked10 }\end{array}$ & 12.33 & 4.11 & 0.27 & 0.63 & 82.66 \\
\hline & Kukus/Steam 10 & 12.15 & 4.43 & 0.31 & 0.06 & 83.05 \\
\hline \multirow[t]{2}{*}{ Kerang/Shell } & $\begin{array}{c}\text { Mentah/ } \\
\text { Uncooked } 10\end{array}$ & 12.17 & 2.83 & 0.25 & 0.24 & 84.51 \\
\hline & Kukus/Steam 10 & 12.44 & 4.35 & 0.29 & 0.32 & 82.6 \\
\hline
\end{tabular}


Tabel 3. Hasil analisis aktivitas air produk patolo dengan penerimaan terbaik Table 3. Water activity analysis of patolo with the best acceptance

\begin{tabular}{lccc}
\hline Ikan/Fish & $\begin{array}{c}\text { Perlakuan/Treatment } \\
(\%)\end{array}$ & $\begin{array}{c}\text { Konsentrasi } \\
\text { Concentration } \\
(\%)\end{array}$ & $\begin{array}{c}\text { Aw Rata-Rata } \\
\text { Average Aw }\end{array}$ \\
\hline Kontrol/Control & $\begin{array}{c}\text { Mentah/ } \\
\text { Uncooked }\end{array}$ & - & 0.46 \\
Uukus/Steam & 10 & 0.46 \\
Ikan beloso/ & $\begin{array}{c}\text { Mentah/ } \\
\text { Lizard fish }\end{array}$ & 20 & 0.46 \\
& $\begin{array}{c}\text { Uncooked } \\
\text { Kukus/Steam } \\
\text { Mentah/ }\end{array}$ & 10 & 0.50 \\
& Uncooked & 10 & 0.45 \\
Kukus/Steam & 10 & 0.45 \\
\hline
\end{tabular}

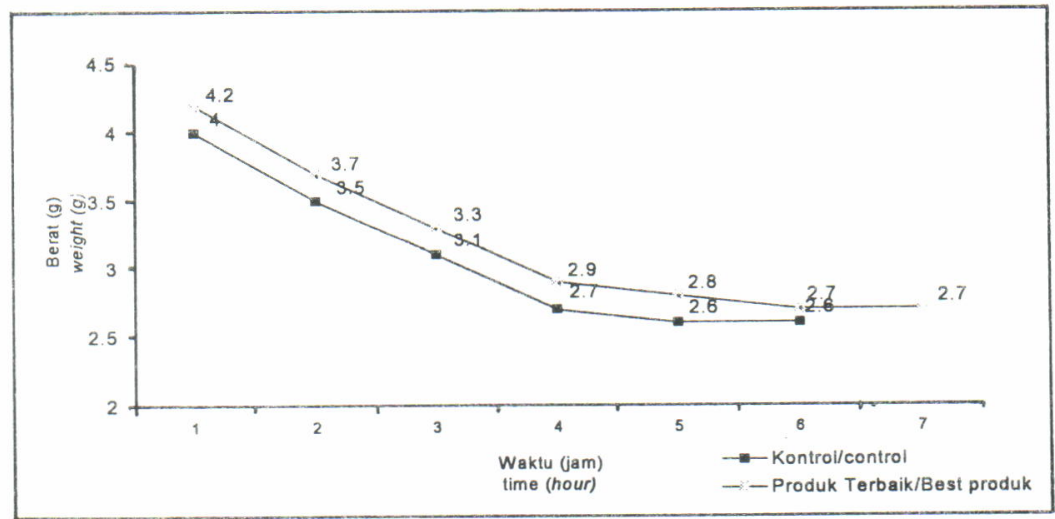

Gambar 11. Penurunan bobot patolo selama pengeringan Figure 11. Decreasing weight of patolo during drying

rendah kadar air suatu bahan makanan nilai aktivitas airnya juga semakin kecil.

\section{Penurunan Bobot Selama Pengeringan}

Dari grafik penurunan bobot (Gambar 11) terlihat bahwa untuk produk kontrol bobot konstan akan dicapai setelah penjemuran jam ke-5, sedangkan untuk produk dengan penerimaan terbaik (penambahan udang kukus $20 \%$ ) bobot konstan dicapai pada jam ke-6. $\mathrm{Hal}$ ini disebabkan karena adanya daging udang dalam produk patolo menyebabkan kemampuan menahan air (water holding capacity) lebih tinggi dibanding kontrol. Suhu penjemuran yang digunakan pada penelitian ini rata-rata $37^{\circ} \mathrm{C}$. Kadar air patolo sebelum penjemuran rata-rata $42 \%$ dan kadar air setelah penjemuran rata-rata $12 \%$.

\section{KESIMPULAN}

1. Fortifikasi pada patolo yang dilakukan dengan penambahan udang, kerang dikukus akan berpengaruh terhadap nilai organoleptik produk.

- Penambahan udang kukus sampai konsentrasi $20 \%$ selain dapat meningkatkan kadar protein juga meningkatkan nilai organoleptik rasa, dan tidak menurunkan semua parameter organoleptik dan daya kembang. Penambahan lebih tinggi akan menurunkan nilai organoleptik penampakan dan warna, bahkan dalam bentuk mentah juga menurunkan nilai organoleptik kerenyahan.

- Penambahan kerang baik mentah maupun dikukus untuk semua konsentrasi meskipun dapat meningkatkan kadar protein produk, tetapi menurunkan nilai organoleptik terutama kenampakan, warna, bau, kerenyahan dan penerimaan.

- Penambahan ikan beloso sampai 
konsentrasi $10 \%$ cukup meningkatkan kadar protein dan tidak menurunkan nilai organoleptik penampakan, bau, rasa maupun penerimaan produk. Akan tetapi penambahan ini menurunkan nilai organoleptik warna dan kerenyahan, penambahan dalam bentuk mentah bahkan menurunkan daya kembang produk.

2. Berdasarkan nilai organoleptik dan peningkatan kadar protein dalam produk maka disimpulkan bahwa jenis ikan yang paling baik ditambahkan pada pembuatan patolo yaitu udang dengan bentuk penambahan dikukus dengan jumlah penambahan $20 \%$. Penambahan ini dapat meningkatkan kadar protein produk dari $1,68 \%$ menjadi $7.01 \%$.

\section{DAFTAR PUSTAKA}

Anggawati, A.M, Erlina, M.D., Murtini, J.T. dan Suherman, M. 1994. Perubahan mutu mie cunang basah selama penyimpanan suhu rendah $\left(10^{\circ} \mathrm{C}\right)$. Jurnal Penelitian Pasca Panen Perikanan (81): 44-45

AOAC. 1980, Official Methods of Analysis. Association of Analytical Chemist. Washington DC. $1018 p$.

Basmal, J., Sugiyono, Peranginangin, R. dan Noor, M. 1995. Pengaruh fortifikasi surimi layang terhadap mutu mie kering selama penyimpanan. Jurnal Penelitian Pasca Panen Perikanan (84): 41- 45.

Ditjen Industri Kecil. 1985. Program Pengembangan Komoditi Andalan Industri Kecil Pangan dalam rangka Keterkaitan Ekspor dan
Pasar Swalayan. Dep. Perindustrian RI. Jakarta.p. 1-7.

Fawzya, Y.N., Anggawati, A.M., Priono, B. dan Sudrajat, $Y$. 1986. Studies on utilization of common carp and nile tilapia for crackers. Jurnal Penelitian Pasca Panen Perikanan (52): 44-52.

Fawzya Y.N., Sugiyono dan Retnowati N. 1994. Pengaruh fortifikasi dari tepung surimi pada mutu roti. Jurnal Penelitian Pasca Panen Perikanan (82): 44-52.

Gomez K.A. dan Gomez A.A. 1995. Prosedur Statistik untuk Analisis Pertanian. Edisi Kedua Terjemahan Oleh: Sjamsuddin, E. dan Baharsjah, J.S. UI Press Jakarta. 697 p

Peranginangin, R., Erlina M.D. dan Ariyani F. $1994^{\mathrm{a}}$. Pengaruh fortifikasi protein dari daging ikan layang (Decapterus macrosoma) lumat dan surimi terhadap mutu mie basah. Jurnal Penelitian Pasca Panen Perikanan (80): 1-11.

Perangin angin, R., Erlina M.D. dan Sugiyono. $1994^{\mathrm{b}}$. Pengaruh tingkat fortifikasi surimi dan penambahan bahan pengawet terhadap mutu mie basah. Jurnal Penelitian Pasca Panen Perikanan (82): 35-43.

Sudarmadji, S., Haryono B. dan Suhardi. 1989. Analisis Bahan Makanan dan Hasil. Pertanian. Liberty Yogyakarta. $172 \mathrm{p}$

Sudarmadji, S., Haryono B. dan Suhardi. 1984. Prosedur Analisis untuk Bahan Makanan dan Hasil Pertanian. Liberty Yogyakarta. 138 p.

Sugiyono, Setiabudi E. dan Peranginangin, R. 1994. Penelitian fortifikasi produk ikan pada kue kering. Jurnal Penelitian Pasca Panen Perikanan (76): 21-31.

Winarno, F.G. 1993. Pangan, Gizi, Teknologi dan Konsumsi PT. Gramedia Jakarta. 97 p. 
